\title{
Beyond the Bifurcated Myth: The Medical Migration of Female Korean Nurses to West Germany in the 1970s*
}

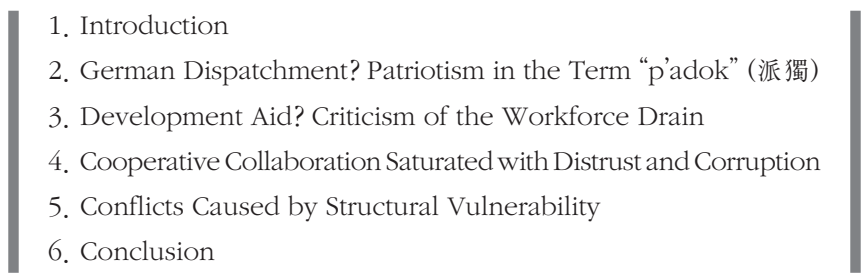

\section{Introduction}

In the Fall of 2013, the National Archives of Korea received records from the German Hospital Federation (Deutsche Krankenhausgesellschaft, abbreviated as DKG) that would contribute to the historical study of the Korean nurses and nurse-aides who moved to the Federal Republic of Germany (FRG) as guest workers in the 1960s and 1970s. The DKG, as the German party in charge of the Program for the Employment of Certificated Korean Nurses and Nurse-aides in German Hospitals from 1971 to 1976, produced and archived documents on Korean employees in 2,527 cases

\footnotetext{
* This work was supported by the Hessian Ministry for Science and the Arts within a research focus programme on "Dimensionen der Kategorie Geschlecht - Frauen- und Geschlechterforschung in Hessen.”

*** Center for German and European Studies, Chung-Ang University, Korea E-mail: yongsuk.jung@gmail.com
} 
that run over 5,000 pages. Their transfer was part of the commemoration project of the 50th Anniversary of the German Dispatchment and the 130th Anniversary of Korea-Germany Diplomatic Relations led by the Korean government.

Research conducted on the medical migration of Korean women to Germany has recently witnessed significant expansion. The first study on this topic was conducted as a social science study in the 1970s by surveying Korean nurses in Germany (Yoo, 1975; Shim, 1975). Research in nursing studies focused on the experiences of nursing care activities of Korean nurses in German healthcare institutions (Park, 2011; Jeong et al, 2017; Eun, 2017) and individual life histories (Kim, Hong, \& Choi, 2009). Na Hye-sim approached this topic as migration history and produced unrivaled research results covering various dimensions, for example, migration processes and motives especially in gender perspectives (Na, 2009b; 2010), working conditions of German hospitals and integration into German society ( $\mathrm{Na}$, 2009a; 2013), and the international political context of labor migration ( $\mathrm{Na}$, 2014; 2016). Other important studies were conducted by Lee You-jae who presented the "development aid" in reverse arguments (Choi \& Lee, 2005), and by Hong Young-sun who explained the recruitment program of nurses as an essential part of "humanitarian aid" by West Germany for the Third World in the context of the international order of the Cold War (Hong, 2015).

One of the biggest difficulties in historicizing the collective experiences of Korean nurses and nurse-aides who moved to Germany comes from the insufficient availability of historical sources. Why is this a problem when the affected people are still alive and have provided extensive oral records and memoirs? The sources for this theme can generally be categorized 
into three main groups: official documents from related German and Korean authorities, the oral records and memoirs of the nurses themselves, and newspaper articles from the period. The mythological story of the "German dispatchment" is based on the narratives of nurses and related persons, published memoirs, and Korean newspaper articles, which mainly deliver the perspectives of Korean nursing staff. The use of documented materials has been limited because the Korean government produced too few records. Na was the first researcher who tried to proffer a historical account on this topic by using official documents produced by German governmental authorities stored in the German Federal Archives (Bundesarchiv) in Koblenz. While her findings are useful mainly for the 1960s, the DKG documents cover the 1970s, the period in which the DKG and the Korean Overseas Development Corporation or KODCO (currently the Korea International Cooperation Agency, KOICA) began to cooperate as business partners.

In spite of their potential significance for the study of Korean care workers who moved to Germany, the DKG records have rarely been used for existing scholarship for two reasons. First, access was restricted because they were in the possession of a private institution. Second, the Korean National Archives, who transferred the documents, also restricts public access because the DKG allowed such a transfer under the condition that they remain confidential, since many documents contained nurses and nurse-aides' personal information. Even other non-confidential documents are not searchable in the catalog list because they were not given codes since they were not being produced by domestic institutions. Therefore, it is difficult to use the records if you do not have detailed information for each document. For this study, I was able to access all the DKG records 
because of research orders from the Korean National Archives in 2013 and 2014 for their translation and organization. Currently, the academic use of these records is authorized on the condition that no personal information be disclosed.

One of the key points to explain the recruitment mechanisms of Asian care workers in German healthcare institutions is the disparity of strength between the sending and receiving states (Hong, 2015: 254). The medical migration of Korean women to Germany was essentially the export of labor from a weak to a strong state driven by the economic and social interests of both states. The cooperative collaboration between the DKG and KODCO could be described as "beneficial to both," as they official contended. However, beneath the surface of a seemingly trouble-free collaboration, there were practical difficulties, bad publicity, mutual mistrust, and cultural misunderstandings. The set of stories comprising the "German dispatchment" myth on the Korean side and the "development aid" discourse on the German side has romanticized such problematics and appropriated the collective experiences of Korean nurses and nurse-aides for their own political purposes. This study tries to investigate beyond this bifurcated myth by focusing on the German side of the story as recoded in the DKG documents.

In the first section, I will review the political aspect of the term "German dispatchment" by demonstrating how it has been used in South Korean society. In the next section, through an analysis of internal discussions held by the DKG to combat criticism of a brain drain, I will disclose the deceitfulness of the discourse of "development aid." In the following section, I will explore the difficulties which developed as a result of the cooperation between related institutions of both countries by inspecting 
cases of administrative incapacity and the pervading corruption of KODCO as investigated by the DKG. Lastly, I will focus on the conflicts between Korean nursing staff and their German colleagues and employers and discuss the origins of these conflicts.

\section{German Dispatchment? Patriotism in the Term “p'adok"(派獨)}

The year 2013 marked the 50th anniversary of Korean miners leaving for Germany because of the so-called Korea Program. The Korean nurses residing in Germany remember their "First Dispatchment Year" as 1966 when Lee Su-kil, a Korean-born physician at the University Hospital in Mainz, began to place Korean nurses and nursing students in some German hospitals. Several exhibitions have been held to commemorate the miners and nurses who worked in Germany. For example, the 2012 exhibitions titled "Youth on the Plane to Germany: The Story of the Miners and Nurses Dispatched to Germany" at the Korean Immigration History Museum in Incheon, and "The Development and Growth of Korea, 1961-1987" at the National Museum of Korean Contemporary History (Kim, 2013). In 2013, two new exhibitions were opened: "Dig Miracles to Save the Country"1) in Gwanghwamun Square and an exhibit showing the dispatchment history at the newly opened memorial hall for the Korean Guest Workers to Germany in Yangjae-dong, Seoul (Joins.com, 2013). In December 2013, an international conference on the Korean nurses and miners in Germany

1) This photo exhibition, promoted by the Great Union Committee in accordance with the inauguration of Park Geun-hye's administration, initially had the purpose of honoring the "dispatched" miners and nurses. It instead instigated controversy by displaying a big picture of former president Park Chung-hee and first lady Yook Young-soo at the exhibition site (Nocutnews.co.kr, 2013). 
was held at the National Museum of Korean Contemporary History. The National Archives simultaneously premiered special documents on the Korean miners and nurses that were transferred from German government agencies, archives, and related institutions at the Seoul Metropolitan Library.

The "p'adok" or "German dispatchment" is a political term referring to Korean labor emigration to West Germany in the Park Chung-hee era in that it glamourizes the labor force export as a patriotic act not only by the government but also by citizens. Park's daughter, who was elected president in 2012 under the platform of continuing her father's political heritage, tried to mythologize him for his economic development through state-sponsored modernization by recalling the story of the miners and nurses who moved to Germany. ${ }^{2}$ 'Their past has been made into "realms of memory" which stimulates nostalgia for Park Chung-hee's era by re-founding his "myth of economic development." ${ }^{3)}$ In this sense, the reverence heat of the "50th Anniversary of Dispatchment" marked the attestation of conservative extremism based on a regressively biased perception of contemporary Korean history by the Park Geun-hye administration.

The recruitment of the Korean nurses for German hospitals was a business between the DKG and KODCO as non-governmental organizations. The latter, as a public corporation, managed the nurse selection in Korea, even

2) The Ministry of Public Administration and Security (MOPAS) was an organization in charge of the National Archives of Korea, which collected foreign records on dispatched miners and nurses. Yoo Chung-bok was the Minister of MOPAS at the time and was known to be close to President Park Geun-hye. In 2014, he was elected as the mayor of Incheon after receiving a nomination from the then ruling party, the Grand National Party.

3) To conceptualize the concept of realms of memory, Pierre Nora focused on establishing a foundation of history through the recollection of memories through archives, monuments, and celebrations (Nora, 1992). 
though it was recognized as a government institution by Koreans wanting to work abroad. The former, as a civilian institution, acted as an agent for German health institutions seeking to employ foreign nurses. The authorities of both Korean and German governments cooperated in the official labor migration process. Prior to this, the DKG's role was managed by private intermediaries including clerical entrepreneurs and for-profit agencies. At that time, the contract conditions varied from hospital to hospital, which led to constant comparison and the desire for nurses to improve conditions. Some brokers illegally claimed commission fees and were involved in bribery and scandals. This was why the recruitment was temporarily halted in 1967.

Since German healthcare institutions still needed a foreign nursing workforce, they looked for ways to hire them legally. From 1971 onward, the employment of Korean nursing personnel in German hospitals became an official business based on an agreement signed by both governments. The Federal Ministry of Labor and Social Affairs (Bundesministerium für Arbeit und Sozialordnung, BMAS), the Korean Embassy in Germany, and the DKG collaborated on drawing up a standard contract that would apply to all Korean nurses and nurse-aides that were recruited for German hospitals. The process was handled by the DKG and KODCO. The DKG received requests from German hospitals and sent the subsequent requests to the Korean Embassy. However, considering that Lee Su-kil as a private intermediary had cooperated with the DKG on investigating the demands of individual German hospitals interested in employing Korean nurses from 1966 to 1967, the DKG had already been involved in the business even before the official agreement. KODCO was responsible for recruiting and preparing nurses in Korea for employment in German hospitals. This 
can be contrasted with examples from other countries that concluded labor migration contracts with West Germany. It was usually West Germany who handled the recruitment processes with other countries, but with Korea, KODCO was granted permission to handle it.

As a result of the First Agreement, 3,744 nurses and 3,289 nurse-aides left for Germany from 1971 to 1974 (Lee, 2011: 89). The DKG and KODCO discussed the details, for example, the estimated annual employment size, training costs, language education, and other employment related matters. ${ }^{4)}$ While the First Agreement specified the number of Korean nurses and nurse-aides needed annually, the Second Agreement in 1974 allowed the number to be decided according to the demands of each employer. The number of nurses and nurse-aides who moved under this agreement remained at 538, and the hiring stopped in 1976. The Second Agreement contained remedial measures to address the issues raised from 1971 to 1974. The main point was that the preparation training process in Korea should be enhanced to expedite Korean nurses' adaptation to work places in Germany.")

KODCO, who undertook this business for ten years from 1966 to 1976," was established in 1965 to export surplus Korean workers to earn foreign currency (Park, 1988). The project involved influential people of the Park Chung-hee government, and this reflects the importance of this national

4) "Note of Understanding," 25 June 1970, Verträge 1974: 151-153.

5) "Kurzprotokoll über das Ergebnis der Beratungen zwischen der DKG und der KODCO zur Weiterführung, Ergänzung und Abwicklung des "Programmes" am 23, 26, 27, 30 Juli und 1 August 1974 in Düsseldorf," 1 August 1974, Verträge 1974: 094-108. For the Korean version refer to $109-122$.

6) See "West Germany Placement of Nurse Agreement." It was concluded between Lee Su-kil of Mainz University Hospital and KODCO president Jung Hee-seob on January 29, 1966. National Archive of Korea. Reg. No. DTA 0011408, pp. 29-30. 
project. The DKG, founded in 1949 as a federation of national and state associations of hospital owners, represented the interests of the German healthcare industry. It supported all relevant hospitals and medical facilities scattered around Germany with the primary goal of helping members solve fundamental problems. The DKG also served as an interest group for all German hospitals that lobbied to negotiate with the healthcare authorities in Germany and abroad to reflect the interests of hospitals in the political decision-making process (Deutsche Krankenhausgesellschaft).

The DKG employed Choi Ki-sik to be in charge of the recruitment of Korean nurses and nurse-aides. He was responsible for communication between the federation and its partners, dealt with issues related to the Korean nursing staff, and drafted most of the related official documents and letters. Previous studies did not reveal his role, even though he received the Federal Service Medal (Bundesverdienstkreuz) from the German government for contributing to the integration of Korean nurses in German society. He is known to have managed Korean nurses and miners migrating to Germany. To briefly explain his background, he was born in Chung-nam, Korea in 1937 and majored in German literature in college. In 1963, he received a scholarship from the German government and studied German as foreign language at the Goethe Institute in Munich and after graduating, he began working as an interpreter and practitioner at the Korean Embassy's Labor Welfare Department in Bonn. From 1972 onward, he worked for the DKG where he was responsible for managing the Korean nurses. ${ }^{7)}$

Apparently, Choi was actively involved in Korean society in Düsseldorf

7) “Bundesverdienstkreuz am Bande für Ki-Sik Choi,” 29 April 1988, Verträge 1974: 001-003. 
JUNG Yong-suk : Beyond the Bifurcated Myth

where the DKG was headquartered. Some letters from Korean activists allow us to presume that Choi was assumed as the patron of Korean immigrants who was responsible for helping them integrate into German society. As a liaison and person-in-charge at the DKG, his role was to identify the cause of conflicts between Korean nurses and hospitals, and to arbitrate these conflicts. He also investigated the problems revealed in the recruitment process of Korean nurses that was managed by KODCO in Korea. Korean nurses and their families in Germany frequently wrote to him for advice and solutions to their work-related, social, and personal issues. He was likely the only native Korean speaker who was well acquainted with affairs in German healthcare institutions.

\section{Development Aid? Criticism of the Workforce Drain}

The goal of the DKG in negotiations with the Korean government in 1970 was to secure as many nurses for the German healthcare industry as possible. The Korean government wanted to send fewer nurses and more nurse-aides, for nurses were also a valuable workforce in Korea. In Korea, the occupation of nurse-aides was founded in 1967 due to a lack of licensed nurses (Korean Nurse Aides Association, 2010: 82-83). It is supposed that the founding of the nurse-aide occupation was due to plans to export them to Germany in place of licensed nurses ( $\mathrm{Na}, 2009 \mathrm{a}$ : 120). Both countries agreed to send five nurse-aides per one nurse. Four years later, the DKG stated that they no longer needed nurse-aides. The Korean government pushed for the same number of nurse-aides to be sent as in the First Agreement, but the DKG refused the offer and insisted that the number should be determined by the needs of each hospital. KODCO 
president Kim Deuk-hwang publicized the contents that were not yet agreed upon regarding the ongoing discussions to the media which led to further confusion. Lauterbacher repeatedly complained about this issue. ${ }^{8)}$

The waiting list of Korean nurse-aides who wanted to work in Germany constantly increased. Applicants who were tired of waiting constantly wrote to Choi in Düsseldorf and asked when they could be called to work in Germany. These letters were written in Korean and directly addressed to him, for he was expected to help them. .' He answered them honestly, but the reply was always the same: that there were few German hospitals hiring nurse-aides and thus the waiting list was long. He could still provide some useful counsel about shortcuts to getting hired, i.e., by contacting certain hospitals that could request them directly and legally without having to go through the list. ${ }^{10)}$ However, they could only contact local hospitals in the rare instances that they had personal contacts or ties to people residing in Germany.

The international community blamed Germany for stealing skilled nurses from a developing country under a development aid justification (Figure 1). This surfaced in Germany while negotiating the First Agreement. In September 1970, both Misereor, a nonprofit organization for aid, and Paulinus, the newsletter published by the Diocese of Trier, criticized the nurse recruitment of German hospitals from Korea and India as "development for Germany" by stealing them from underdeveloped

8) Lauterbacher's daily report on 26 March 1974, Korea Programm 1970-1975 t.2: 367-370.

9) Letter from a Korean nurse working in Berlin, dated January 19, 1974 (in Korean), asking for a recruitment opportunity for her sister who was trained as a nurse-aide, see in Gesundheit 1971-1981: 146.

10) For examples of Choi's responses in Korean, see Gesundheit 1971-1981: 012, 139, 189. 
countries. ${ }^{11)}$ Reinhold Rörig, Executive Secretary of the Hospital Federation of Rhineland-Palatinate, tried to defend the German healthcare industry. ${ }^{12)}$ First, he argued that Misereor's criticism that German hiring was causing nurse staffing shortages was based on incorrect news and media reports. He emphasized that the nurse shortage in Korea was not caused by German hiring. He could not completely deny that a shortage existed in the underdeveloped countries that sent nurses to German hospitals; instead he focused on weakening the causal chain between shortage and German hiring. Second, he emphasized that the hiring process was an official program agreed to by both governments. He tried to avoid domestic criticism by explaining that Korea was promoting this program with an economic motivation. Finally, he argued that the three years of experience the Korean nurses gained in Germany would contribute to the technological and economic enhancements of Korean society. However, concerning how the nurses would readapt to Korean society after returning, Rörig simply reiterated that they would not have any difficulty reintegrating back into their own society. ${ }^{13)}$

11) "Entwicklungshilfe für Deutschland - Anwerbung von Krankenschwestern aus Südkorea und Indien?" Paulinus, 17 September 1970, Korea Programm 1970-1975: 349.

12) Rörig, as Director of the Mainz Hospital where Lee Su-kil worked in 1966, helped Lee with the recruitment process.

13) “An die Redaktion des Trierer Bistumsblattes Paulinus," Letter from Rörig to editorial of Paulinus dated 30 July 1970, Korea Programm 1970-1975: 345-348. 
Figure 1. A campaign against the import of nurses from the Third World in Der Spiegel on May 8, 1972

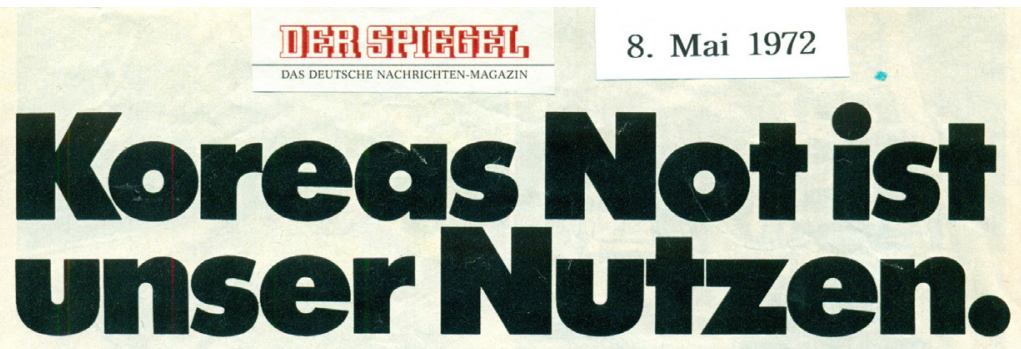

Die Gesellschaft der Bundesrepublik ist unfähig, für ihre Kranken und Alten selber zu sorgen: Bis 1980 werden bei uns 90.000 Schwestern und Krankenpfleger fehlen.

Darum importieren wir sie.Von den Philippinen, aus Indien. Vor allem aus Korea. Wir brauchen sie. Korea braucht sie dringender.

30 Prozent aller koreanischen Schwestern arbeiten heute bei uns. Obwohl in Korea allein in den Städten 26 Prozent der Schwesternstellen unbesetzt sind.

Wir haben sie hierher geholt. Opfer eines weltweit ungerechten Systems. Niemand kann ihnen vorwerfen, daß sie ihre Chance wahrnehmen. Die Chance, Geld zu verdienen. Erfahrungen zu sammeln. Sich zu emanzipieren.

$\mathrm{Zu}$ kritisieren sind wir: Durch die $\mathrm{Ab}$ werbung von Schwestern verweigern wir Koreanern ihr Recht auf Gesundheit. Mißachten ihre Menschenwürde.

Die Vermarktung von Schwestern und Ärzten aus den Ländern der Dritten Welt in den reichen Nationen ist Entwicklungshilfe in verkehrter Richtung. Jedenfalls solange wir versäumen, in Zusammenarbeit mit koreanischen Partnern alles zu tun, damit auch in Korea ein Gesundheitssystem entsteht, das koreanischen Kranken die gleichen Chancen gibt wie uns Patienten reicher Nationen.
Auch unsere kirchlichen Krankenhäuser kommen ohne ausländisches Pflegepersonal nicht aus. Auch wir haben kein Patentrezept zur prinzipiellen Lösung des Problems. Aber Verschweigen hilft uns allen nicht weiter. - Deshalb weist

Weltmission darauf hin, daß der Abzug der medizinischen Fachkräfte aus der Dritten Welt Sünde ist. Daß die Probleme der Entwicklungsländer in Wahrheit ihre Wurzeln in den Industrienationen haben.

\section{Weltmission Heute sind wirPartner}

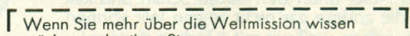
I möchten, schreiben Sie uns:

Evangelische Weltmission

I 2000 Hamburg 13, Mittelweg 143

I Name

I Anschrift

I Und hier erhalten Sie Informationen über das

I Internationale Katholische Missionswerk MISSIO:

I Bitte ausschneiden und auf eine frankierte

Postkarte kleben.

Source: National Archives in Korea 
JUNG Yong-suk : Beyond the Bifurcated Myth

The German government was also concerned about receiving such criticism. Walter Arendt as Federal Minister for Labor and Social Affairs promised that Germany would not hire nurses from countries where there was a shortage. ${ }^{14)}$ The Economic Cooperation Federal Minister warned German hospitals that they could no longer hire leftover nurses trained in institutes in developing countries, because they were needed in their own countries to expand and improve their healthcare facilities. ${ }^{15)}$ The DKG was aware of this. Jörg Lauterbacher, the deputy director of the DKG, in his visit to Seoul in 1971, discussed contract conditions for the First Agreement, accentuating the following statement in his interview with Dong-A Ilbo: "The contracts would take into consideration the domestic requirement of the Korean people for the nursing personnel." ${ }^{16)}$ However, such efforts were futile, for they could not avoid heated discussions with the Korean medical group.

The day after Lauterbacher's interview, a provocative contribution titled "Which Is More Important. To Save Money or Lives?" by Dr. Kit G. Johnson was published in The Korea Times. Johnson, a public health doctor and professor at Yonsei Severance hospital in Seoul, was infuriated by the removal of nurses from the already deficient Korea. He likened the recruitment program to the African slave trade; the Korean government was selling their people in return for hard cash. He calculated the average annual sum of money that could flow back to Korea. After predicting the average annual economic return to Korea, subtracting expenses from the

14) Deutsche Ärzteblatt, July 1970.

15) "Beschäftigung von Krankenschwestern aus Entwicklungsländern," Letter from Economic Cooperation Federal Minister to Rörig on 7 September 1970, Korea Programm 1970-1975: 342-344.

16) Dong-A Ilbo, 27 February 1971, Korea Programm 1970-1975: 022. 
nurses' wages, and dividing the number by the average annual extra deaths in Korea caused by the absence of nurses, he concluded that "a Korean life is only worth 100 dollars in hard currency." ${ }^{17)}$

Johnson's position was based strictly on the humanitarian perspective that the economic development of Korea was not worthy for it was solely geared towards increasing quality of life. His anger also reflected the position of Koreans in the medical field who were having difficulties due to the shortage of skilled nurses. It was obvious that with hundreds of nurses disappearing annually, hospitals and clinics located in the countryside and small cities would not function well without having a sufficient workforce. Johnson was able to speak out against the state-sponsored enterprise because he was a foreign elite from an advanced capitalistic country. The Korean government did not use the word "export" and tried to romanticize it by calling it "dispatchment." However, foreign experts in the medical field dispassionately called it labor force export.

The DKG swiftly but carefully responded to Johnson's accusation. The article containing Lauterbacher's counterargument was published five days later. He carefully discussed the logic behind his argument. He defended the German recruitment program, noting that it served as an opportunity for many young Korean women to educate themselves. This would also enable them to acquire professional skills and to gain necessary workplace experiences. Furthermore, these women could contribute to the interests of the Korean people after their return with the professional skills acquired in Germany. In conclusion, he maintained that the export of nurses benefited both countries, which was the DKG's official position. ${ }^{18)}$

17) The Korea Times, 28 February 1971, Korea Programm 1970-1975: 021.

18) "Letters to the Editor: Nurses Abroad," The Korea Times, 4 March 1971, Korea Programm 
However, Lauterbacher's counterargument did not directly rebuke Johnson's criticism. Johnson only pointed out the drain of licensed nurses and their educational levels being higher than that of German nurses. Lauterbacher ignored this so that the chance for professional training could only be applied to nurse-aides and not to licensed nurses. The export of licensed nurses had to be translated into a potential loss rather than a benefit for Korean society in other aspects as well. The Korea Times reported a case where a foreign government hesitated to approve a project financing a nursing school in Korea because it would help Germany and not Korea. ${ }^{19)}$ All the newspaper articles published in Korea on recruiting Korean nurses for Germany were scrupulously scrapped in the DKG file folders, since it prevised the trend of public opinion in Korea and in the international community which could influence the recruitment arrangement.

After debates between Johnson and Lauterbacher, Dr. Patricia A. Conroy, who was working at the Maryknoll Hospital in Busan and cooperated with the Korean Nurses Association as a chairperson of the education committee, provided a third opinion. She emphasized that her point of view was different from that of Johnson, the DKG, and the Korean government. She paid attention to Korean nurses' own motives for moving to Germany, which included personal gains, such as earning more money, education, and experience abroad. She shared Johnson's concern in that there was a shortage of nurses in Korea and predicted that requests for Korean nurses would also come from the US and Canada, further exacerbating the shortage. However, it was an excellent opportunity for

1970-1975: 015.

19) "Letters to the Editor: Potential Nurses," drawn up by D. J. Mulder M. D. in The Korea Times, 14 March 1971, Korea Programm 1970-1975: 010. 
nurse-aides to gain professional training and their departure did not signify Korea's loss of a professional workforce. She concluded that the nurse exports to Germany were beneficial to both Korean society and the nurses themselves. ${ }^{20)}$

Conroy was rather skeptical about how the acquired German experiences of the Korean nurses would contribute to the development of the Korean medical field. The acquired skills would remain useless once they returned to Korea, because they would not be practiced in the Korean medical field. This was caused by the Korean societal tradition of women quitting their jobs at a certain age to get married. Thus, in Korea, the nursing occupation was short-lived and women only pursued it for an average of five years before getting married. Going to Germany meant that they would be trained for three years and would soon get married and quit. Furthermore, the nursing license acquired in Germany was not accepted in Korea. Hence, she contested that without examining the measures to help returning nurses and nurse-aides readapt to Korean society and continue working, the dispute between Lauterbacher and Johnson was rather meaningless.

\section{Cooperative Collaboration Saturated with Distrust and Corruption}

On June 30, 1971, a letter was delivered to the German Embassy in Seoul from the Korean Association of the Training Schools for Nurse Aides. It contained complaints of KODCO breaking the agreement on open recruitment for nurse-aides. Instead it gave preferential treatment to KODCO sponsored training schools by privately sending their nurse-aides

20) The Korea Times, 12 March 1971, Korea Programm 1970-1975: 013-014. 
to Germany. The same letter was delivered to Dr. Lee Su-kil who reported it to the DKG Director Müller and requested a thorough investigation. ${ }^{21)}$ Four months later, the DKG responded that "after conducting an internal investigation, the allegations against KODCO were unfounded" and tried to cover up this problem. ${ }^{22)}$

The DKG did not want to be concerned with the recruitment process; they only wanted to receive the necessary nursing labor force. The reports of KODCO receiving bribes from applicants came from several sources. After a report by a Bundestag member, the DKG began a covert internal investigation of KODCO's administrative management in the summer of 1971 and suspected a Korean in a high ranking position in KODCO as being responsible for the unfaithful implementation of the agreement. ${ }^{23)}$ It asked for immediate intervention from the Federal Minister for Labor and Social Affair. ${ }^{24)}$ The DKG did not want its business partner's corruption handled publicly, for it had just quelled bad publicity in Germany and Korea. However, if the sustainability of the business was questioned and therefore German hospitals' interests were challenged, the DKG preferred to solve the issue indirectly by pressuring the German and in some cases also the Korean governments.

The DKG reacted sensitively to the credibility of health checkups of applicants among KODCO's corruption allegations, for this was directly

21) Letter from Lee Su-kil to Müller on 27 August 1971, Korea Programm 1970-1975 t.1: 084-086.

22) Letter from Lauterbacher to Federal Ministry for Labor and Social Affairs and to Korean Embassy in Bonn on 11 November 1971, Korea Programm 1970-1975 t.1: 071-072.

23) DKG internal document written on 15 July 1971 was sent to Lauterbacher, Korea Programm 1970-1975 t. 1: 047.

24) Letter from Lauterbacher to Dr. Ernst as Secretary of Federal Minister for Labor and Social Affair on 10 September 1971, Korea Programm 1970-1975 t.1: 039-042. 
linked to the interests of German hospitals. Choi Ki-sik visited Korea from April to May 1973 and found that KODCO did not execute health checkups of applicants according to Germany's demand. Article nine of the Korea Program, which was titled, 'Medical Expert's Opinion, Therapeutical or Prophylactical Precautions concerning Vermination and Vaccination,' required every nurse and nurse-aide selected to be medically examined by doctors authorized for that purpose by the Korean Ministry of Health and Social Affairs, under the supervision of the Office of Labor Affairs. Also, regardless of the result of the medical examination, the applicants were also treated with the appropriate drugs (e.g. "Alcopar") under medical supervision to protect against any kind of vermination (e.g. ascaris lumbricoides, trichiuris trichiura, ankylostoma duodenale, trichostrongylus orientalis, Clonorchis sinensis, paragonimus westermani) and vaccinated in accordance with international and German health requirements. ${ }^{25)}$ The certificates of medical examination issued by KODCO Hospital in Seoul seemed flawless on paper, ${ }^{26)}$ but in practice, it was common for medical practitioners in Korea to skip a few checkup items and leave out important testing tools like screening for tuberculosis and treatment for parasitic diseases. $^{27)}$

Deficient physical examinations often led to serious problems. In 1974, a nurse-aide was diagnosed with pulmonary tuberculosis after arriving at a municipal hospital in Munich. To her relief, she was not fired by

25) See "Program for the Employment of Qualified Korean Nurses and Nurse-Aids in German Hospitals" in Verträge 1974: 067-085.

26) For example, see the "Letter of Physical Examination" of a 20 -year-old nurse-aide dated 24 September 1971 in Korea Programm 1970-1975 t. 2: 056-061.

27) Letter from Federal Ministry of Labor to DKG on 3 October 1973, Korea Programm 19701975 t. 2: 062-063. 
the hospital and could return after receiving medical treatment with a guaranteed vacation pursuant to German Labor Law. The hospital required KODCO to pay the expenses incurred from the improperly conducted physical examination, which would include the one-way airfare paid by the employer to bring the nurse over to Germany and the loss caused by her inability to work during the treatment period. Since nursing work requires extensive physical labor, the hospital deemed that sick employees would not be able to perform their duties, and that they would spend the three years of their contract receiving treatment before returning home. ${ }^{28)}$ Other cases included a nurse who was fired immediately after being diagnosed with salmonella poisoning after arriving in Germany, ${ }^{29)}$ and a nurse who returned home early after being diagnosed with mental illness ${ }^{30)}$ Furthermore, a nursing home complained of receiving nurses with cardiac disorders. ${ }^{31)}$ As a consequence, German hospitals distrusted health checkups conducted in Korea and asked the DKG to double check so as to not incur unnecessary additional costs. ${ }^{32)}$

The disorganized selection and delivery of nurses by KODCO caused recurrent problems. Between October 30 and November 1, 1973, 103 nurses were expected in Germany, but only 38 arrived. KODCO explained

28) Letter from Munich city to KODCO on 3 July 1974, Gesundheit 1971-1981: 131-132.

29) Before returning, she could be treated because of the proposal by the Bernhard-Nocht Institute for tropical medicine in Hamburg. See the letter from the German Red Cross Nurses Association Hamburg Branch to DKG on 13 February 1973, Gesundheit 19711981: 116.

30) Letter from the German Red Cross Nurses Association East Prussia Branch to DKG on 6 January 1973, Gesundheit 1971-1981: 125-126.

31) Letter sent to DKG by the German Workers' Welfare Association (AWF) on 26 January 1973, Gesundheit 1971-1981: 136.

32) "Vermittlung koreanischen Krankenpflegepersonals durch die KODCO" dated 10 October 1973, Korea Programm 1970-1975 t.2: 053-055. 
that this was due to a delay in visa issuance. ${ }^{33)}$ However, Choi Ki-sik suspected bribery. In 1967, the German embassy in Korea reported to the Department of Foreign Affairs about the unsystematic nurse recruitment process. Turning in passports for visa issuances only a few hours before departure was common and the list of selected nurses for departure changed countless times even while they were waiting at the airport (Yun et al, 2013: 27-28). It is speculated that nurses who did not pay brokerage fees were replaced by those who did. On January 12, 1973, Franz Weyand, the manager of the travel agency, Flugtourist, which transported Korean nurses and nurse-aides to Germany, reported KODCO’s handling fees in an interview with Die Zeit. He stated that the official passport fee and stamp tax was "only" 110 German mark which was surely not a small amount to Koreans. ${ }^{34)}$ A comparable report was delivered by Ms. Griseldis Ende who was delegated to Seoul as the director of the short-term German language training program for Korean nurse applicants.

Lauterbacher was outraged and wrote to the Korean Embassy in Bonn condemning these "shameful" behaviors, expecting that this would be relayed to KODCO.${ }^{35)}$ Its president, Han Sang-joon, formally responded that such a recurrence will be prevented, but he did not disguise his feelings of inconvenience about the DKG meddling in the Germany-Korea formed institutions. The DKG was all too aware of it. That is why they approached solving the problems they deemed serious by appealing to governmental

33) "Organisatorische Fehlleistung der KODCO bei der Abwicklung des Charterfluges 31. Okt./1. Nov. 1973," Report by Choi Ki-sik to Müller on 15 November 1973, Korea Programm 1970-1975 t.2: 073-077.

34) Archiv des Deutschen Caritasverbandes d.V. (ADCV) 380.40.047 Fasz.01

35) "Vermittlung koreanischen Krankenpflegepersonals durch die KODCO," Letter from Lauterbacher to Korean Embassy in Bonn on 10 October 1973, Korea Programm 19701975 t. 2: 064-065. 
authorities of both countries by asking for reform indirectly and sometimes demanding strict prevention.

Distrust in KODCO was one of the reasons why Korean applications for work in Germany persisted through unofficial private routes even after the official agreement in 1971. ${ }^{36)}$ It was conducted through for-profit agencies that had managed German recruitments before the DKG was in charge. For example, Corporation Ahnjin in Seoul did not go through either KODCO or the DKG and contacted Haus Lindenbrunn Hospital in Hannover directly to supply 30 male nurse-aides. ${ }^{37)}$ When the hospital naively asked the DKG to accept them, it emphasized to the hospital the illegality of such hiring and cautioned that the quality of the workforce would not be guaranteed. ${ }^{38)}$ Furthermore, it notified the related agency after a thorough investigation that the person who mediated between the Haus Lindenbrunn Hospital and Ahnjin was a former Korean employee of the German embassy in Seoul. ${ }^{39)}$

In 1971, Korean nurses who were suspicious of KODCO for only selecting nurses from a certain nursing school, asked Lee Su-kil to continue mediating between nurses and German hospitals. The list of 279 applicants was delivered to him by the Korean Nurse Association and the Korean Nurse Aides Association in December 1972. However, the DKG made it clear that

36) Letter from DKG to Heinz Kühn as Prime Minister of North Rhine-Westphalia on 8 September 1971, Korea Programm 1970-1975 t.1: 144-146.

37) "Sehr geehrter Herr Choi," Letter from Haus Lindenbrunn Hospital to Choi Ki-sik on 6 March 1973, Auseinandersetzungen 1974-1993: 041-045.

38) "Anwerbung koreanischer Krankenpflegehelfer von der Firma Ahnjin in Seoul," 19 March 1973, Auseinandersetzungen 1974-1993: 038-039.

39) "Anwerbung koreanischer Pflegekräfte; hier: Verletzung des deutschen Arbeitsordnungsrechtes durch die Firma Ahnjin, Seoul und deren Vertreter in Deutschland, Herrn Chung, Hyung-Soo, Hamburg," 21 March 1973, Auseinandersetzungen 1974-1993: 032-037. 
nurse hiring in German hospitals was only possible through KODCO and also sent this information to KODCO as a cautionary measure. ${ }^{40)}$ Internally, the DKG was troubled by KODCO's corruption scandals, but officially only noted that all the nursing personnel who want to work in Germany are guaranteed equal opportunities. Obviously, no Korean prospective applicants believed this, and private brokerage continued. ${ }^{41)}$

\section{Conflicts Caused by Structural Vulnerability}

Müller, the Director of the DKG, complained in a letter to Jin Pil-sik, the Korean Ambassador in Bonn, on July 4, 1974 about Kang Won-yong, the director of the Christian Academy in Seoul and chairperson of the German Committee in Korea, about his reports to the Rheinische Post concerning Korean nurses' dissatisfactions in their work environments including working, living, and contract conditions. Müller reasoned that Korean nurses and nurse-aides working in German hospitals had nothing to complain about since they were guaranteed the same rights as their German coworkers and their education and welfare were supported financially by the DKG. ${ }^{42)}$ He was worried about German hospitals getting a bad reputation for employing foreign nurses.

40) "Unmittelbare Bewerbung von 79 Krankenschwestern und 200 Krankenpflegehelferinnen aus Korea um eine Beschäftigung in deutschen Krankenhäusern,” Letter from Lauterbacher to Han Sang-joon as the President of KODCO on 8 January 1973, Korea Programm 1970-1975 t.2: 112-113.

41) For an example, see "Bewerbung von 79 Krankenschwestern und 200 Krankenpflegehelferinnen aus Korea um eine Beschäftigung in deutschen Krankenhäusern über eine private koreanische Organisation," Letter from Lauterbacher to Bae Kun-ho as Labor Consultant at Korean Embassy in Bonn on 21 August 1973, Korea Programm 19701975 t. 2: 086-088.

42) "Lebens- und Vertragsbedingungen koreanischer Krankenschwestern in der Bundesrepublik Deutschland,” Korea Programm 1970-1975 t.2: 379-381. 
The German Caritas Association reported a completely different account of the issue. Foreign nurses in Germany experienced many personal problems, and Asian women in particular faced difficulties settling into German society because they received more discriminatory treatment. ${ }^{43)}$ Hong interpreted such difficulties as symptoms of "pervasive racism" which viewed Asian women as backward people who needed to be taught the classic German virtues of work, punctuality, order, and cleanliness (Hong, 2015: 254, 277). Others deliver rather moderate arguments on the topic. The difficulties which Korean nurses and nurse-aides experienced in German hospitals angered them because they perceived them as evidence of discrimination, but after several decades, they tended to describe the difficulties in the early years as the consequences of a mutual misunderstanding (Eun, 2017: 125). This alteration in their perception can be explained as a result of their assimilation following a lengthened stay as vocational nurses in German society (Na, 2009a: 113-114).

On April 9, 1974, one of four Korean nurse-aides working at the city hospital of Borkum located near the North Sea was fired and another two received suspensions for "failing to fulfill dut[ies]," "promoting disorder in the workplace," and "rejecting certain tasks." ${ }^{44)}$ The suspended nurses protested that the measures were unjustifiable. They argued that accusations of "promoting disorder in the workplace" was unfair because they strictly followed the discipline established by chief nurses, and "failure in duty" and "reject[ion] of certain tasks" does not apply either because they had

43) "Information des Deutschen Caritasverbandes zur Situation der Asiatinnen in der BRD," Reports on Asian women living in German written by Caritas Association Freiburg Branch on 9 April 1974, Korea Programm 1970-1975, t.3: 292-306.

44) "Koreanische Krankenpflegehelferinnen," Letter from Borkum city to DKG on 9 April 1974, Auseinandersetzungen 1974-1993: 098, 100-101. 
been caused by a change in their working hours without prior notification. They argued that they were victims. ${ }^{45)}$ The incident had begun with miscommunication between a Korean nurse-aide and her supervisor. She had ordered the Korean nurse-aide to come to her "immediately (sofort)," to which the Korean nurse-aide responded, "I'll be right over (gleich)." Her German supervisor was angry that the nurse-aide disobeyed her order, while the Korean nurse-aide could not determine what was wrong with her reply, as she had simply meant that she would assist the supervising nurse as soon as she was done with her current task. From reading between the lines of this case, there was a considerable amount of tension between the German and Korean staff. The emotional strain and misunderstanding escalated into serious tension. For example, German nurses were often dismissive of their Korean coworkers, for they found them to be "noisy," ${ }^{60)}$ while the Korean staff complained that they were left with janitorial work. ${ }^{47)}$

The DKG file folders contain numerous documents on Korean nurses and nurse-aides describing hardships and homesickness. Some women were disappointed with their workplaces and succeeded in obtaining early terminations by complaining of bad working conditions. University hospitals in big cities were popular workplaces, while psychiatric hospitals, hospitals in the countryside, and nursing homes that required intensive physical labor were generally shunned. Many looked for alternative placements and moved arbitrarily. The problem was, if they did not get

45) See statements of the fired nurse-aide on 23 April 1974 in Korean, Auseinandersetzungen 1974-1993: 133-139. For German translation, see "Darstellung der Sachlage" in 106-115.

46) Letter from Borkum city to the fired Korean nurse-aide on 27 May 1974, Auseinandersetzungen 1974-1993: 076-077.

47) Letter to the fired Korean nurse-aide from her lawyer on 17 May 1974, Auseinandersetzungen 1974-1993: 166-167. 
their employer's consent in doing so, it was a breach of contract which resulted in the cancellation of their work and residence permits. In such cases, they sought Choi's help. Here is an example.

Mr. Choi, I am very sorry to ask you for a big favor. Today, I made a call at post office and came back and submitted my resignation formally. I feel sorry for the nursing home, but I think they get along with me since they feel sorry for me, too. (...) We have so much to learn and there are so much we don't know. Nobody knows how much I regretted when I got here. It was just heartbreaking. I had to bite back and could not ask anything. (...) May I ask you for a hard favor? You know well. I would rather like to move to a good place where there are not too many or too few Korean people, of course with no Korean men, and with good working conditions. I know, I am a greedy person. One of my classmates from KODCO works at the Bonn University Hospital and I'd like to move there. If you have information about better place than this, please let me move there. If you think the Bonn University Hospital also good, please let me move there. I do not know at all, so I want you make the best for me. (...) You must be annoyed with me. I feel so sorry. But I cannot take it anymore. I can put up with hardships, but I feel uneasy here. Right, I came to Germany to work, but I cannot stay like this. I hope you help us. (... ${ }^{48)}$

Choi had to develop a formal letter for such cases written in Korean with blank spaces for the names and workplaces, since these cases continued to occur. Certainly, not all these cases were as a result of mistakes or misinformation about the consequences of contract breaches. Many of the early terminations of Korean nurses was to move to a workplace that

48) Dated on 4 and 12 November 1973, Gesundheit 1971-1981: 143-144 (in Korean, translated by author). 
presented them with better conditions, since they worked hard to come to Germany.

Most of the letters sent by Korean nurses, nurse-aides, and others asking Choi's help were handwritten in Korean and only a few were translated into German, usually only in cases of legal disputes. It is questioned if there was any room for him to maneuver as the liaison and person-in-charge at the DKG to intervene on behalf of Korean nurses in this space created by the strategic use of Korean, both by him and his "clients." It is more likely that he would not have archived such letters, because he seemed to handle such difficulties, especially concerning early terminations from the side of the Koreans, with "German inflexibility." In some cases, he simply noted the consequences of arbitrary breaches of contract to the nurses who sought his help. ${ }^{49)}$ In other cases, supposedly with consent, he helped them move to other hospitals after receiving pledges with sincere apologies and promises not to repeat the same exercise. ${ }^{50)}$ The pledges were handwritten in Korean and not translated into German, which means that Choi required them for his own purposes, for example, recurrence prevention by calling attention to them, and not to make them accessible to his supervisor.

German employers complained of early resignations by their Korean employees. At the Haus Lindenbrunn Hospital, two Korean nurse-aides wanted to quit because of marriage. Their official excuses were that one had to quit to move for her husband's job and the other one to become a homemaker. ${ }^{51)}$ However, both nurses gave their notice of resignation on

49) For an example, see Choi's reply dated January 18, 1974 (in Korean), Gesundheit 19711981: 165

50) For an example, see a pledge by a Korean nurse dated December 4, 1973 (in Korean), Gesundheit 1971-1981: 145 .

51) Notice of resignation by Korean nurse-aides on 10 May 1973, Auseinandersetzungen 
the same date, May 10, and asked to be terminated together on June 30. The hospital was suspicious and asked the DKG if marriage was included in the "significant excuse" clause outlined in the contract. ${ }^{52)}$ Lauterbacher could only ambiguously respond that it was difficult to judge the legality and validity of marriage as a resignation excuse and that interpretations could result due to cultural differences. ${ }^{53)}$ Some hospitals clamored for countermeasures at the institute level to combat this problem that was prevalent across Germany. ${ }^{54}$

The differences in the nature of nursing in Korean and German hospitals was one of the biggest conflicts between Korean nurses and their employers. On September 6, 1971, Dr. W. Bartsch wrote to the DKG complaining about two Korean nurses who were employed at the Waldsanatorium Urbachtal in central Germany. His sanatorium was focused on recuperation and thus did not require any intensive physical exertion and he treated the Korean nurses very hospitably. However, the nurses did not follow hospital instructions and insisted that their primary nursing duties were medication treatments and injections only, and they complained that the wages paid according to the hospital regulations were discriminatory. ${ }^{55)}$

The level of nursing work in German hospitals was in principle divided into three categories: basic nursing duties, advanced nursing

1974-1993: 029, 030 .

52) "Kündigungen von koreanischen Krankenpflegekräften," Letter from Haus Lindenbrunn Hospital to Lauterbacher on 14 May 1973, Auseinandersetzungen 1974-1993: 026.

53) "Kündigungen von koreanischen Krankenpflegekräften aus Anlass deren Verheiratung," Reply from Lauterbacher to Haus Lindenbrunn Hospital on 27 June 1973, Auseinandersetzungen 1974-1993: 024-025.

54) Auseinandersetzungen 1974-1993: 028, 048, 049, 055-056, 064-065.

55) "Tätigkeit der koreanischen Krankenschwester," Letter from Dr. Bartsch at Waldsanatorium-Urbachtal to DKG on 6 September 1971, Korea Programm 1970-1975 t. 1: 093-095. 
duties (including providing medication and administering injections), and specialized nursing duties involving anesthetics and working in operating rooms. However, nurses completed the first two categories without separation. This came as a shock especially to Korean licensed nurses, for their level of nurse education was at the higher or college level, while in Germany it was a secondary education. There was a big difference in the number of required theory acquisition hours: Korean nurses had 2,400 to 2,900 hours and German nurses had 1,200 hours of classes (Yu, 2014: 370). However, in German hospitals, all Korean nurses, regardless of whether they were nurse apprentices, nurse-aides, or nursing practitioners, had to perform tasks from cleaning to nursing. In the beginning, when they could not speak German fluently, they were mostly in charge of cleaning and kitchen work, and it shocked them.

Hospital officials searched for the cause of the troubles using the assumed filter of cultural misunderstandings and developed an educational program known as Model Course or Modellkurs. This program started in the last year of the First Agreement in Borken, Westphalia by the Klausenhof Academy that was responsible for educating foreign workers from developing countries. All nurses from Asia were required to receive four weeks of intensive training here before hospital placements. ${ }^{56)}$ Participation requests were to be made by the hospitals and not from the individual nurses, and hospitals did not have to pay for training costs and participants were paid 200 marks as compensation instead of a wage. The DKG director Müller recommended this program to hospital directors highly.

56) "Beschäftigung koreanischer Krankenpflegekrfte. hier: Vorbereitung der Pflegekräfte auf die Tätigkeit in Ihrem Krankenhaus,” 5 April 1974, Auseinandersetzungen 1974-1993: 680-682. 
The program focused on training nurses and nurse-aides in the German language, which included medical terminology, to understand German society and their hospital duties. ${ }^{57)}$ Sociologists, psychologists, social workers, and nurse instructors taught employment laws, foreigner laws, the German healthcare system, hospital system, and care systems for the elderly. Out of the various programs, 'the hospital system and care program' stands out as a 16-hour long curriculum, which especially emphasizes the importance of manual work, compared to nurse aides and the AmericanEnglish system, and details the working methods in German hospitals, such as bed making, preparation of various teas, volcanic mud bath etc. ${ }^{58)}$ It states the goals of the program, i.e., preventing conflicts by ensuring that Korean women understand that basic nursing tasks were required of them. Model Course was an educational program originally developed for Korean nurses, was judged to be successful, and was extended to additional nurses from other developing countries, such as the Philippines.

It is difficult to draw a clear line between cultural misunderstanding and racism in these cases of conflict, for it is true that they occurred due to different perceptions of nursing in both countries. However, beneath the surface of misunderstanding, the main reason for the difficulties was rooted in the vulnerability of female migrant laborers from an underdeveloped part of Asia. The phrase, cultural misunderstanding was a diplomatic expression for the unilateral interpretation of conflicts on the part of

57) "Berichte über den ersten Modellkurs des Bundesministeriums für Arbeit und Sozialordnung zur sprachlichen Ausbildung von koreanischen Krankenschwestern an der Akademie Klausenhof in Borken vom 21.4.74-22.5.74,” 31 May 1974, Verträge 1974: 170-180.

58) "Modellmaßnahme zur Einfhrung koreanischer Krankenschwestern in Gesellschaft und Arbeitswelt der Bundesrepublik,” Auseinandersetzungen 1974-1993: 413-415. 
German employers, which caused the structurally vulnerable position of their guest employees to remain invisible.

\section{Conclusion}

In the history of the medical migration of Korean nurses and nurseaides to West Germany, the period from 1971 to 1976 is characterized by governmental cooperation which was conducted through a partnership between non-governmental organizations, i.e., the DKG on the German side and KODCO on the Korean. The administrative relations between them were a cooperative collaboration. However, under the surface of the cooperative practice of workforce recruitment lay the problems which resulted from the very nature of the recruitment mechanism based on the disparity of state strength, i.e., labor transfer from a weak to a strong state. This was the structural context in which the Korean nurses and nurseaides seeking job opportunities in West Germany were positioned in the global labor market. As "ghosts of the Park Chunghee era" (Kim, 2011) and as guest workers in an expanding post-industrial welfare state, they were forced into subaltern positions in both countries.

One of the contributions of this article to existing scholarship on the history of Korean female nurses who moved to Germany is that it endeavored an examination of the topic from a fresh perspective by using newly released documents. It discloses the deceitfulness and fictitiousness of the "German dispatchment" myth on the Korean side and the "development aid" discourse on the German side; thus, historicizing the medical migration of Korean women to West Germany beyond the bifurcated myth. While the former served to romanticize the export of a labor force driven by 
a profit-seeking Korean government, the German healthcare institutions pushed the latter to defend themselves from blame relating to a workforce drain from the Third World. In recent years, many studies have objected to the Korean labor migration to Germany. The DKG records are expressive, for they are the official documents of an organization that speak for the German side which has received little attention. While these documents do not result in completely new findings, they are still meaningful for providing concrete evidence on the circumstances of that time that were only inferred before, and especially for informing the position and views of the German healthcare industry in handling the exposed problems.

Securing the necessary nursing care laborers was an important project for the West German healthcare industry in the 1960s and 1970s amid social security expansion and an aging population explosion. The DKG's main task was to represent and protect the interests of its member hospitals; it had no difficulty in rationalizing the recruitment of nursing laborers from developing countries as being beneficial to both sides. It was aware of the current preoccupation of the Korean government with measurable economic gains and an emphasis on the export of laborers. It was also aware that "educational aid" was only an elegant business justification for taking nursing personnel out of healthcare institutions in underdeveloped countries that desperately needed them. This is why it tried to avoid the issue in response to the criticism of workforce drains.

KODCO, as the only route for Korean nurses and nurse-aides to be employed in German hospitals since 1971, became the target of suspicion by Korean citizens and its German partners, because there were constant allegations of bribery in exchange for job brokering. The incapacity and corruption of KODCO resulted in the exploitation of Korean applicants 
wanting to work in Germany and German healthcare institutions seeking Korean nursing personnel. Furthermore, such scandals could threaten the stable sustainability of the recruitment business by stimulating bad publicity in both countries. This is why the DKG repeatedly and covertly investigated KODCO's bribery scandals. Despite the rumors being mostly true, the DKG still maintained that there were no administrative problems in the KODCO management concerning recruitment. Instead, every time complaints from its member hospitals surfaced, for example, due to losses caused by improper nurse selection, the DKG tried to rectify the problem through an indirect but stern approach.

"Mutually beneficial" was the magic phrase that justified the transnational business of the export of medical labor from South Korea to West Germany. The latter maintained its growing health industry and the former obtained foreign currency which was acutely needed. Was it beneficial to the nurses, too? It could be an opportunity for a better life for them, as emphasized by the German perspective. However, their vulnerable position as female guest workers from an underdeveloped part of Asia frequently resulted in tension and conflicts related to nursing tasks and working conditions. Korean nurses were often an overeducated workforce tasked with performing basic nursing tasks and were desperately disappointed. Since they did not move so far away for nothing, they were sometimes overzealous in bringing forth the best possible outcome while working in a foreign country with an unfamiliar language and culture. This often clashed with ethnic principles in the workplace, because the difficulties with female guest workers from Asia were generally shifted to their inadequacy to adhere to the German style of work. The concept of "cultural misunderstanding," which was adopted by German employers 
JUNG Yong-suk : Beyond the Bifurcated Myth

and was accompanied by the suspicion of pervasive racism, provided a formal argument for appeasing these difficulties and dissatisfactions.

Key words: German dispatchment, development aid, Korean nurses and nurse-aides, guest worker, medical migration, German Hospital Federation (DKG), Korean Overseas Development Corporation (KODCO), workforce drain, bribery and corruption, cultural misunderstanding. 


\title{
REFERENCES
}

\author{
$\langle$ Primary Sources〉
}

Deutsche Krankenhausgesellschaft: Koreanische Krankenschwester File Folders:

- Auseinandersetzungen 1974-1993: 024-025, 026, 028, 029, 030, 032-037, 038-039, 041-045, 048, 049, 055-056, 064-065, 076-077, 098, 100-101, 133-139, 106-115, 166$167,413-415,680-682$.

- Gesundheit 1971-1981: 012, 116, 125-126, 131-132, 136, 139, 143-144, 145, 165, 189.

- Korea Programm 1970-1975: 010, 013-014, 015, 021, 022, 342-344, 345-348, 349.

- Korea Programm 1970-1975 t.1: 039-042, 047, 071-072, 084-086, 093-095, 144-146.

- Korea Programm 1970-1975 t. 2: 053-055, 056-061, 062-063, 064-065, 073-077, 086088, 112-113, 367-370, 379-381.

- Korea Programm 1970-1975 t.3: 292-306.

- Verträge 1974: 001-003, 067-085, 094-108, 109-122, 151-153, 170-180.

Archiv des Deutschen Caritasverbandes d.V. Sig. ADCV 380.40.047 Fasz.01

National Archive of Korea. Reg. No. DTA 0011408, pp. 29-30.

Deutsche Ärzteblatt, July 1970

\section{〈Secondary Sources〉}

Chang-Gusko, Young-Seoun, ed., Unbekannte Vielfalt. Einblicke in die koreanische Migrationsgeschichte in Deutschland (Köln; DOMiD, 2014)

Choi, Sun-ju and Lee, You-jae, "Umgekehrte Entwicklungshilfe. Koreanische Arbeitsmigration nach Deutschland," Kölnischer Kunstverein et al, ed., Projekt Migration. Ausstellung zum "Projekt Migration"... vom 30. September 2005 bis 15. Januar 2006 im Kölnischen Kunstverein und an zwei weiteren Orten in Köln (Köln: DuMont, 2005), pp. 831-832.

Eun, Young, "P'adok kanhosaui kanhogyongghom [Nursing Care Experiences of Korean Nurses Dispatched to West Germany]," Kun'gwanjolgon'gangghakhoeji [Journal of Muscle and Joint Health] 24-2 (2017), pp. 119-129.

Hong, Young-sun, "Entwicklungsutopien und globale Identitäten: südkoreanische Krankenschwestern in der Bundesrepublik Deutschland in den 1960er und 
JUNG Yong-suk : Beyond the Bifurcated Myth

1970er Jahren,” Hubertus Büschel and Daniel Speich, eds., Entwicklungswelten. Globalgeschichte der Entwicklungszusammenarbeit (Frankfurt am Main: Campus Verlag, 2009), pp. 207-240.

Hong, Young-sun, Cold War Germany, the Third World, and the Global Humanitarian Regime (Cambridge: Cambridge Univ. Press, 2015).

Joung, Sun-ei, Kim, Soon-ae, Kim, Sook-young, and Lee, Joo-young, "1960-70nyondae p'adokkanhosaui munhwagaldunggwa chaajongch'esong [Cultural Conflicts and Self-identity with Germany-dispatched Korean Nurses in the 1960s and 1970s]," Han'gugent'ot'einmont'usanophakhoenonmunji [Journal of the Korea Entertainment Industry Association] 11-3 (2017), pp. 71-86.

Kim, Seong-bo, “Ssongch'ari kyoryotodoen 'yoksainsik posudaeyonhap'ui konggan, taehanmin'gugyoksabangmulgwan [The National Museum of Korean Contemporary History: a Venue for Conservative Alliance in Historical Consciousness without Introspection]," Yoksabip'yong [Critical Review of History] 103 (2013), pp. 132-160.

Kim, Hack-sun, Hong, Sun-woo, and Choi, Kyung-sook, "P'adokkanhosa salmui chaejomyong [Recapturing the Lives and experiences of Korean Nurses dispatched to Germany in the 1960s and 1970s]," Han'guksanopkanhohakhoeji [Korean Journal of Occupational Health Nursing] 18-2 (2009), pp. 174-184.

Kim, Won, Pakchongihui sidaeui yuryongdul. Kiok. sagon kurigo chongch'i [Ghosts of the PARK Chung-hee Era. Memories, Episodes, and Politics] (Seoul: Hyonsilmunhwa, 2011)

Korean Nurse Aides Association, Kungmin'gwa hamkkehan kanhojomusa 45nyonsa [History of Nurse Aids for 45 years 1965-2010] (Seoul: Korean Association of Nurse aides, 2010)

Lee, Ae-joo et al, eds., P'adokkanho: p'yonggasaop ch'oejongbogoso [The Final Report of the Evaluation on the Germany-dispatched Nurse Projects] (Seoul: Malgeun, 2011)

Na, Hye-sim, “Togirui taehan'gaebarwonjosa yon'gu: mijereorul chungsimuro [A Study on the History of German Development Aid for Korea: With Much Focus on Misereor]," Togil Yon'gu [Korean Journal of German Studies] 35 (2017), pp. 123163.

Na, Hye-sim, "Diplomatische Tauschgeschäfte? Eine alternative Ansicht zur 
Gastarbeiterschaft im Rahmen eines asiatischen Beispiels," Historische Zeitschrift 302 (2016), pp. 677-702.

Na, Hye-sim, “Togirui taehan'gaebarwonjowa hanin yosongui nodongiju: kaebarwonjo tamnon'gwa ku silch'esaieso [Korean people's German emigration: Between labour migration and development aids]," Togil Yon'gu [Korean Journal of German Studies] 28 (2014), pp. 37-68.

$\mathrm{Na}$, Hye-sim, “T'uraensunaesyonol kwanjomeso pon togil hanin'ganhoijuui yoksa : yangguk kanhomunhwae taehan yonghyangul chungsimuro [The Influence of Korean Nurses' Immigration into Germany on the Nursing Culture and Policy of the Countries: A Transnational Perspective]," Uisahak [Korean Journal of Medical History] 22-1 (2013), pp. 179-215.

Na, Hye-sim, Togillo kan hanin kanho yosong [Korean Nursing Care Women Gone to Germany] (Seoul: San Kwa Gul, 2012)

Na, Hye-sim, "1960-1970nyondae hanin'ganhoillyok togirhaengui wonin [What made Korean Nurses Move to West Germany during 1960 1970]?” Soyangsaron [Korean Journal of Western History] 100 (2010), pp. 255-285.

$\mathrm{Na}$, Hye-sim, "Togil hanin'ganhoyosongui nodongui songgyok [Labor characteristics of Korean nurses in Germany]," Togil Yon'gu [Korean Journal of German Studies] 17 (2009a), pp. 111-140.

$\mathrm{Na}$, Hye-sim, "Haninyosongganhonodongjaui togirijuwa hanin'gajok nae yosongui yokhal [Korean female nurse workforce's migration to Germany and women's role in Korean families]," Yosonggwa yoksa [Women and History] 11 (2009b), pp. 43-74.

Nora, Pierre, Realms of Memory: Rethinking the French Past, Vol. 1. Conflicts and Divisions (New York: Columbia Univ. Press, 1992)

Park Lae-young, ed., Han'gugui haeoegaebal. oje, onul, kurigo naeil [Overseas Employment of Korean. past, present, and future] (Seoul: Asansahoebokchisaopchaedan [ASAN Foundation], 1988).

Shim, Yun-jong, "Haeoe ch'wiobinui silt'ae - chaedok han'gukkanhowonul chungsimuro [Condition of Korean overseas employment Korean nurses in Germany]," Inmun'gwahak nonmunjip [Essays in Human Sciences] 2-7 (1975), pp. 18251838.

Yoo, Do-jin, Die Situation Koreansicher Krankenpflegerkraft in der Bundesrepublik 
JUNG Yong-suk : Beyond the Bifurcated Myth

Deutschland und ihre Sozialpaedagogischen Probleme (Kiel: Dissertation, 1975)

Yu, Jin-young, "P'adok kwangbukanho illyogui kungnae mit togiresoui kyoyuk pigyo(1963 1977) [Education of Korean Mineworkers and Nurses in Germany, 1963-1977]," Pigyogyoyugyon'gu [Korean Journal of Comparative Education] 24-1 (2014), pp. 351-376.

Yun, Yong-seon, Jung, Heung-mo, Yu, Jin-young, Na, Hye-sim, and Noh, Meunghoan, Kwangbukanhosarul t'onghae pon p'adogui yoksajok uimiwa yonghyang yon'guyongyok ch'oejongbogoso [Research Report: Dispatch of Korean Miners and Nurses to Germany. Its historical Meaning and Influences] (Seoul: Taehanmin'gugyoksabangmulgwan [National Museum of Korean Contemporary History], 2013)

Yun, Yong-seon, “1960-70nyondae p'adok illyoksongch'urui misisa: tongwonin'ga, sont'aegin'ga? [Korean Guestworkers in Westgermany in the 1960-70s: Mobilization or Choice]?" Sach'ong 81 (2014), pp. 421-450.

Noh, Meung-hoan, “Naengjon sidae pakchonghuiui han'guk sanophwa chongch'aekkwa sodogui uimiwa yokhal 1961-1967 [The Meaning and Role of the Federal Republic of Germany for the Industrialization of the Republic of Korea at the Beginning of the Park Chung-hee Era under the International Cold War System 1961-1967]," Sarim 38 (2011), pp. 289-323.

$\langle$ Online Articles〉

Mission and Objectives, Deutsche Krankenhaugesellschaft. http://www.dkgev.de/dkg. php/cat/257/aid/10696. Accessed 8 June 2017 and 10 January 2018.

"Soul yangjaedonge p'adokkullojaginyomgwan kaegwan [Memorial Hall for the Korean Guest Workers to Germany opens in Yangjae-dong, Seoul],” joins.com, 21 May 2013. http://news.joins.com/article/11577868. Accessed 10 January 2018.

“'Pakchongjhui hyangsu nollan' p'adok honjong sajinjon...ttaeanin ch'ebul nollan [Dispatchment exhibition reminiscent of PARK Chunghee controversy. Unreasonable overdue wages controversy]," nocutnews.co.kr. 5 November 2013. http://www. nocutnews.co.kr/news/1125873\#csidx93fab22f1bbcfb89b46 bfb91f4a537c. Accessed 10 January 2018. 


\title{
Beyond the Bifurcated Myth: The Medical Migration of Female Korean Nurses to West Germany in the 1970s
}

\author{
JUNG Yong-suk*
}

This study investigates beyond the bifurcated myth of the medical migration of Korean women to Germany in the 1970s, which is known as the "German dispatchment" myth from the Korean perspective and the "development aid" discourse from that of the Germans, by focusing on the newly-released documents from the German Hospital Federation (Deutsche Krankenhausgesellschaft, DKG). The migration was essentially a transfer of labor from a weak to a strong state, and the disparity of state strength characterized the nature of the recruitment mechanism. Both Korea and Germany have romanticized the labor transfer and appropriated the collective experiences of migrants for their own political purposes. In this transnational business, the Korean Overseas Development Corporation (KODCO) and the DKG maintained exclusivity in the labor migration channel and were faithful to their own interests.

The DKG, as a representative of the German healthcare industry, was

\footnotetext{
* Center for German and European Studies, Chung-Ang University, Korea E-mail: yongsuk.jung@gmail.com Received: Jan. 31, 2018; $\quad$ Reviewed: Feb. 20, 2018; $\quad$ Accepted: Jul. 25, 2018
} 
concerned about being criticized for destroying the healthcare system of developing countries by stealing their skilled workforce. They, therefore, tried to influence publicity in Korea and Germany to persuade the people that the recruitment benefited both countries. However, the DKG was aware of the deceitfulness of its "development aid" discourse. The Korean government, which advanced the labor export for the sake of obtaining foreign currency, romanticized it as patriotism and used the term "German dispatchment." However, the incapacity and corruption of KODCO as an agency from the Korean perspective resulted in criticism regarding its recruitment program. The DKG complained that the selection of incapable personnel coupled with corruption was causing unforeseen financial damage to its member hospitals. Nevertheless, it officially defended its partner for the sake of its own interests, such as avoiding bad publicity and securing the sustainability of the recruitment program. The conflicts regarding nursing tasks and working conditions between Korean nurses and their German colleagues and employers captured in the documents of the DKG trace the origin of the issues in relation to cultural misunderstanding and pervasive racism. The disparity of state strength between the two countries resulted in the subaltern position of Korean female healthcare workers in the global labor market, and they tried to bring forth the best possible outcome while working in a foreign country in unfamiliar circumstances. However, the difficulties with female guest workers from Asia were generally credited to their inability to adhere to the German working style.

This study contributes to the existing scholarship on this topic by filling the gaps. Historical research on the medical migration of Korean nurses and nurse-aides to West Germany has relied on limited historical sources. In 2013, the National Archives of Korea transferred official documents 
regarding these workers that were produced and archived by the DKG, which represented the interests of German healthcare institutions. Its documents on Korean nursing personnel provide supplementary information and display findings in different perspectives. They do not bring forth completely new findings that have never been researched before but are still valuable for delivering concrete evidence on the circumstances of that time, which were previously merely inferred.

Key words: German dispatchment, development aid, Korean nurses and nurse-aides, guest worker, medical migration, German Hospital Federation (DKG), Korean Overseas Development Corporation (KODCO), workforce drain, bribery and corruption, cultural misunderstanding. 
